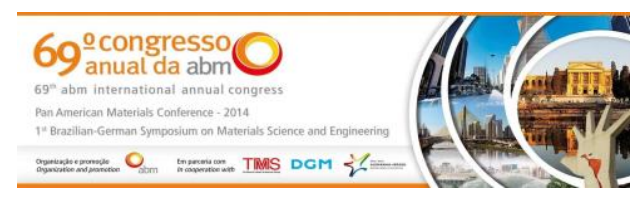

Tema: Metalurgia Física

\title{
EFFECT OF COLD ROLLING ON TEXTURE, ANISOTROPY AND MICROSTRUCTURE OF ANNEALED MARAGING 350 STEEL*
}

Nathanael Wagner Sales Morais ${ }^{1}$ Hamilton Ferreira Gomes de Abreu²

\section{Resumo}

Os aços maraging tem grande importância tecnológica devido sua aplicação nas industrias aeroespacial e nuclear. Uma das aplicações para esse material é a fabricação de cilindros de alta resistência pelo processo de estampagem profunda, logo o conhecimento da textura cristalográfica torna-se fundamental. Este trabalho investigou o efeito da laminação à frio seguida por um recozimento sobre a microestrutura, textura e anisotropia plástica no aço maraging 350. A anisotropia foi medida pelo cálculo dos coeficientes de Lankford e dos coeficientes de anisotropia normal $(R m)$ e planar $(\Delta R)$. Os resultados mostraram o aumento na deformação a frio gera um aumento na intensidade da fibra $<111>$ acompanhada de um aumento no valor de Rm. As análises metalográficas mostram que maiores reduções induzem à um precipitação intermetálica após o recozimento.

Palavras-chave: Maraging 350; Textura; Anisotropia

\section{EFFECT OF COLD ROLLING ON TEXTURE, ANISOTROPY AND MICROSTRUCTURE OF ANNEALED MARAGING 350 STEEL}

\begin{abstract}
Maraging steels have a great technological importance due their application in the aerospace and nuclear industries. One of these applications is a deep drawing for a fabricate cylinders of high strength, so knowing the mechanical behavior of this steel is critical to a good drawing. This paper evaluates the texture, anisotropy and the microstructure of maraging 350 steel after cold rolling and annealing. The anisotropy was measured by the calculation of Lankford's coefficients and the calculation the normal $(\mathrm{Rm})$ and planar $(\Delta \mathrm{R})$ anisotropy coefficients. It was found that increasing cold rolling reduction before the annealing strengths the $<111>$ fibre texture and improves the $\mathrm{Rm}$. The microstructural analysis shows that great rolling reduction could induce intermetallic precipitation after the annealing in this steel.
\end{abstract}

Keywords: Maraging 350; Texture; Anisotropy.

1 Engenheiro Metalurgista, Msc. doutorando, Laboratório de Materiais Nucleares, Centro de Tecnológico da Marinha em São Paulo, Campo Experimental ARAMAR, Iperó, São Paulo, Brasil.

2 Engenheiro Naval, PhD. Professor Associado, Departamento de Engenharia Metalúrgica e Materais, Universidade Federal do Ceará, Fortaleza, Ceará, Brasil.

* Contribuição técnica ao $69^{\circ}$ Congresso Anual da ABM - Internacional e ao 14ํㅡㄹ ENEMET - Encontro Nacional de Estudantes de Engenharia Metalúrgica, de Materiais e de Minas, 21 a 25 de julho de 2014, São Paulo, SP, Brasil. 


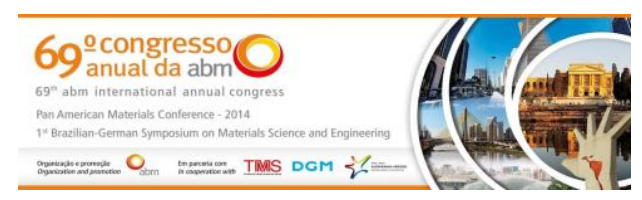

\section{INTRODUÇÃO}

Maraging steels are Fe-Ni-Co-Mo-Ti alloys with a low carbon content, that have a great application in aerospace, war and nuclear industries. Because it is soft martensite in the annealed condition this material shows a high plasticity in contrast with the high mechanical resistance in aged condition. In this steel the main hardener alloying element is the $\mathrm{Ti}$, controlling the amount of $\mathrm{Ni}_{3} \mathrm{Ti}$ formed during the aging [1]. According to Abreu [2], the cold deformation of a polycrystalline material can induce the formation of a preferential orientation on grains, leading to a deformation crystallographic texture. Hosoya et. Al [3] proved that the recrystallization texture on maraging steels is similar to the other cold deformed BCC metals, transmitting to annealed condition a strong $\mathrm{Y}$ fiber and other paper [4] show that is possible to find the cube on edge component. Abreu [4] shows that the a deformation texture is weakened after the annealing of the maraging 350 , but some components is strengthened by aging. Figure 1 shows sections of $\varphi 2=45^{\circ}$ of the ODFs for some conditions of maraging 350 steel.
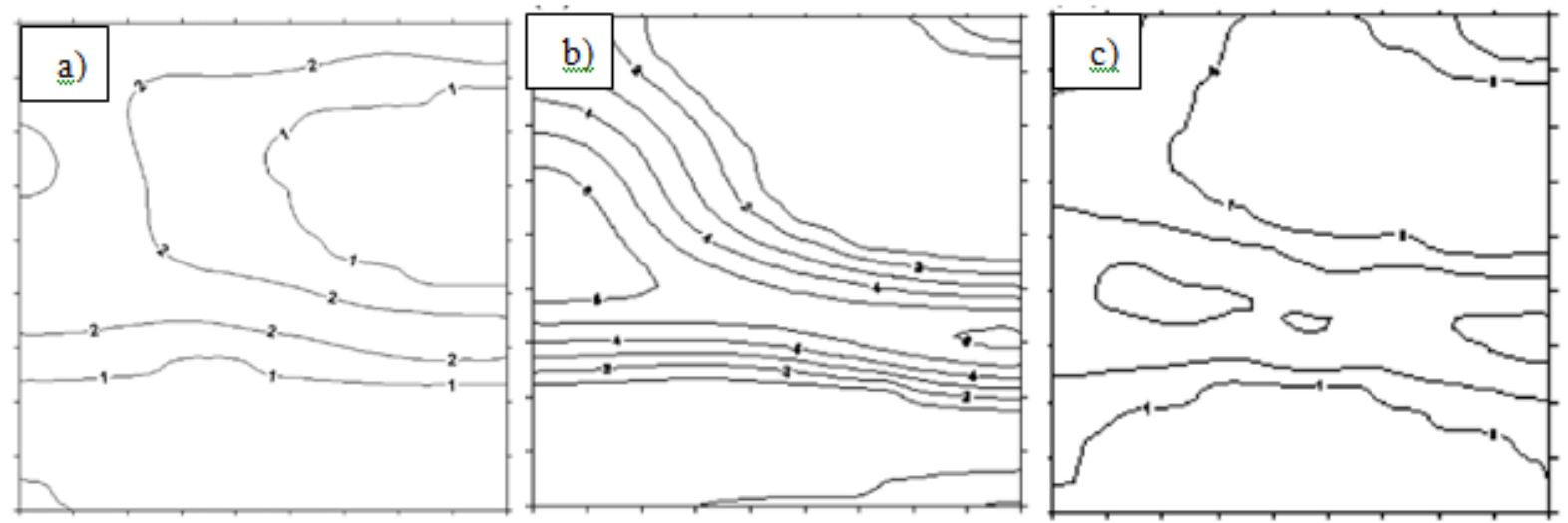

Figure 1. Sections of $\varphi 2=45^{\circ}$ for the ODFs of maraging 350 steel in a) hot rolled condition to $60 \%$ of thickness, b) Cold rolling with a reduction of $80 \%$ in thickness and, c) Annealed to $820^{\circ} \mathrm{C}$ for $1 \mathrm{~h}$.

The crystallographic texture has strong influence on material's properties anisotropy. In the papers, there is no information about the anisotropy behavior of maraging steels in annealed condition.

One method to measure the plasticity anisotropy of a material is determining the Lankford's coefficients defined by the Eq.1

$$
R=\varepsilon_{y} / \varepsilon_{z}
$$

Were $\varepsilon_{y}$ is the true deformation on normal direction and $\varepsilon_{z}$ is the true deformation on transverse direction in a tensile test. With the $R_{0}, R_{45}$ and $R_{90}$, the $R m$ (planar anisotropy coefficient), defined by Eq.2, and $\Delta \mathrm{R}$ (normal anisotropy coefficient), defined by Eq. 3, can be calculated.

$$
\begin{array}{r}
R m=\left(R 0+2^{*} R 45+R 90\right) / 4 \\
\Delta R=\left(R 0-2^{\star} R 45+R 90\right) / 2
\end{array}
$$

In a good material for deep drawing the values of $\mathrm{Rm}$ are higher than 1 to avoid a excessive wall thinning during the drawing [5], and a desired value $\Delta R$ is close to zero to avoid the formation of ears after the drawing [6]. In the Figure 2, the effect of $\Delta R$ can be observed in the drawing of a cup [7].

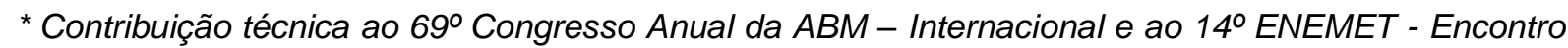
Nacional de Estudantes de Engenharia Metalúrgica, de Materiais e de Minas, 21 a 25 de julho de 2014, São Paulo, SP, Brasil. 

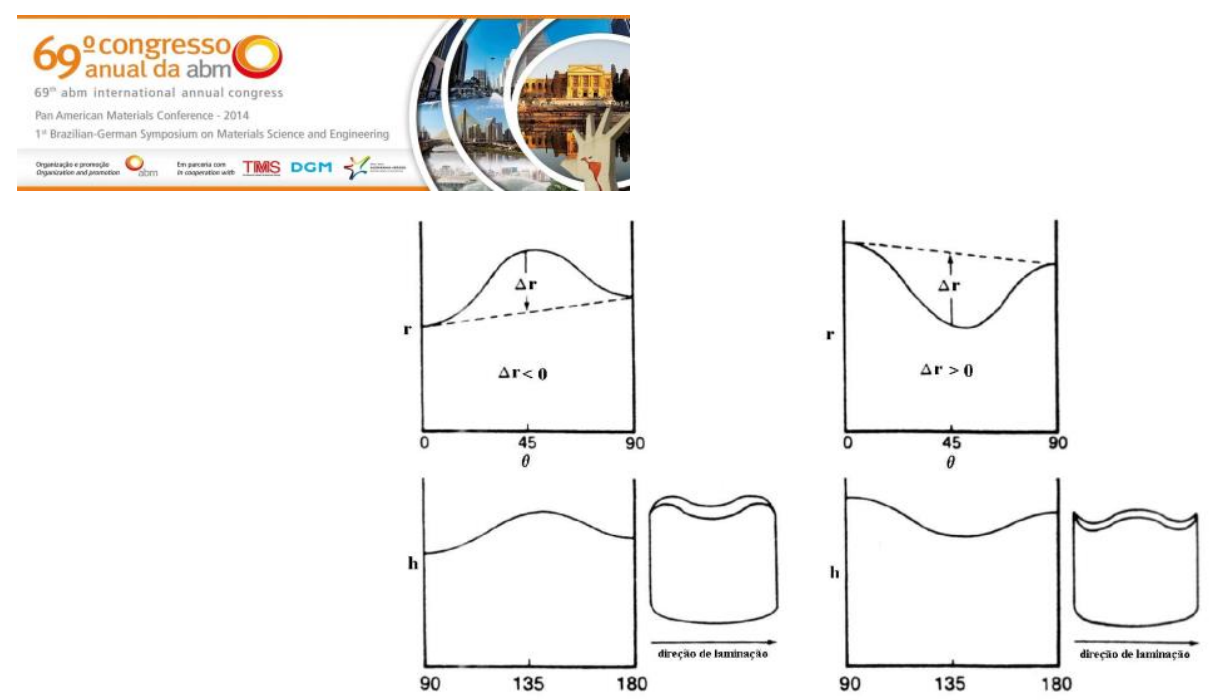

Figure 2. Effect of $\Delta \mathrm{R}$ parameter on deep drawing.

\section{EXPERIMENTAL PROCEDURE}

The chemical composition of the maraging steel used on this paper is shown on the Table 1. This steel was provided by Brazilian Navy in forged condition. The received steel was initially annealed on $900^{\circ} \mathrm{C}$ for $1 \mathrm{~h}$ and after this was cold rolled in a LE 200 B roller provided by SENAI DR-CE, on Maracanaú Industrial District. The reduction by cold rolling was performed to reduction on $50 \%, 70 \%$ and $80 \%$ on thickness reduction and after the rolling the samples was annealed in a muffle furnace EDG 6P at $900^{\circ} \mathrm{C}$ for $1 \mathrm{~h}$. The identity of the samples is shown on Table 2.

Table 1. Chemical composition of Maraging 350 steel

\begin{tabular}{ccccccc}
\hline Steel & $\mathrm{Ni}$ & $\mathrm{Co}$ & $\mathrm{Mo}$ & $\mathrm{Ti}$ & $\mathrm{Al}$ & $\mathrm{Fe}$ \\
\hline Mar350 & 18,19 & 12,17 & 4,85 & 1,38 & 0,28 & $\mathrm{Bal}$ \\
\hline
\end{tabular}

Table 2. Identification of Samples

\begin{tabular}{ccc}
\hline Deformation & Colling & Identity of sample \\
\hline Cold Rolled $50 \%$ & Coll. Furnace & M350L50F \\
\hline Cold Rolled $70 \%$ & Coll. Furnace & M350L70F \\
\hline Cold Rolled $80 \%$ & Coll. Furnace & M350L80F \\
\hline
\end{tabular}

The samples used to measure the pole figures were corroded with a acid solution [40 ml H2SO4 + $40 \mathrm{ml} \mathrm{H} 2 \mathrm{O}+20 \mathrm{ml} \mathrm{HNO} 3$ ] to avoid the gridding damage to surface. A Phillips X'Pert diffraction system equipped with a Co target tube was used to collect data from texture analysis. A optical microscope Olympus BX51M and a SEM XL30 was used for perform the microstructural analysis. The samples used in metallography was etched with modified ferrous chloride $[2,5 \mathrm{~g} \mathrm{FeCl} 3.6 \mathrm{H} 2 \mathrm{O}+20 \mathrm{ml}$ $\mathrm{HNO} 3+40 \mathrm{ml} \mathrm{HCl}+40 \mathrm{ml} \mathrm{H} 2 \mathrm{O}$ ] for 20s [8].

The calculation of the ODF performed with the POpla software and the sections of $\varphi 2=45^{\circ}$ was plotted with the MTEX software package.

The tensile tests for calculation of Lankford coefficients was performed on a EMIC DL 10000 using a strain rate of a $1 \mathrm{~mm} / \mathrm{min}$ and the geometric measuring of the samples was based on the ASTM E8/E8M [9] procedure are shown on Figure 3 and Table 3.

* Contribuição técnica ao 69ํㅡㄹ Congresso Anual da ABM - Internacional e ao 14 ENEMET - Encontro Nacional de Estudantes de Engenharia Metalúrgica, de Materiais e de Minas, 21 a 25 de julho de 2014, São Paulo, SP, Brasil. 

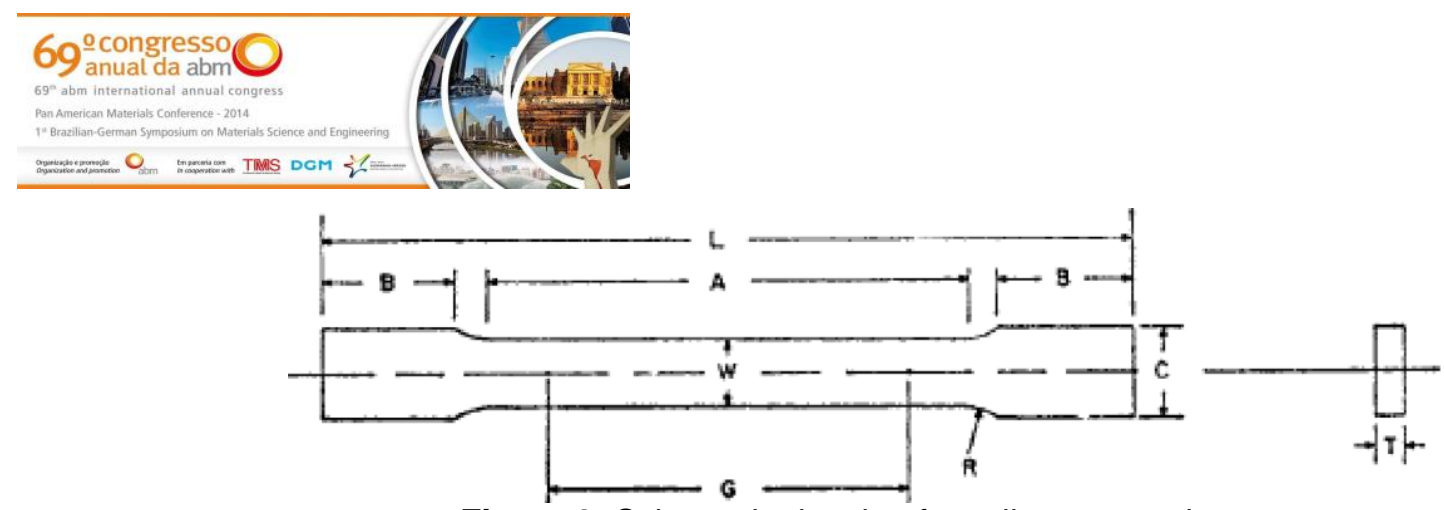

Figure 3. Schematic drawin of tensile test specimen.

Table 3. Geometric measuring of tensile tests specimen.

\begin{tabular}{ccccccc}
\hline Sample & L & B & A & W & C & T \\
\hline M350L50F & $40 \mathrm{~mm}$ & $16 \mathrm{~mm}$ & $8 \mathrm{~mm}$ & $4 \mathrm{~mm}$ & $10 \mathrm{~mm}$ & $5 \mathrm{~mm}$ \\
\hline M350L70F & $40 \mathrm{~mm}$ & $16 \mathrm{~mm}$ & $8 \mathrm{~mm}$ & $4 \mathrm{~mm}$ & $10 \mathrm{~mm}$ & $3 \mathrm{~mm}$ \\
\hline M350L80F & $40 \mathrm{~mm}$ & $16 \mathrm{~mm}$ & $8 \mathrm{~mm}$ & $4 \mathrm{~mm}$ & $10 \mathrm{~mm}$ & $2 \mathrm{~mm}$ \\
\hline
\end{tabular}

The extra-reduced specimens were made because the low quantity of available material and a previous work was made with a extra-reduced specimen [10].

\section{RESULTS AND DISCUSSION}

\subsection{Metallographic Analysis}

The metallographic analysis of the received samples show a common microstructure, Figure 4, of an high Ni maraging steel, showing no precipitates in the microstructure.

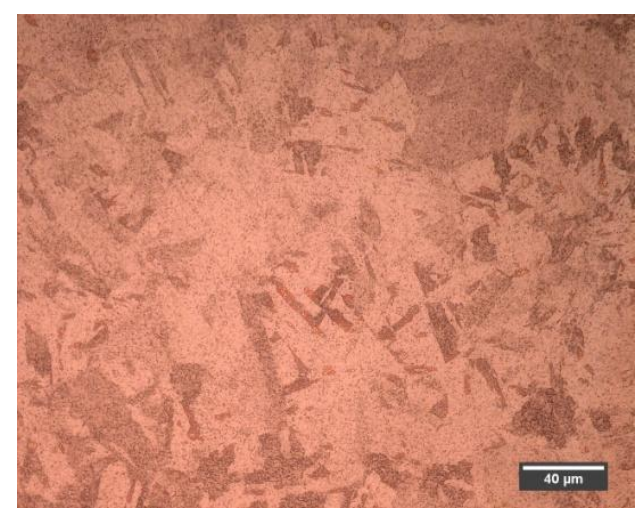

Figure 4. Optical micrograph for the received condition

The optical micrographs for the M350L50F and M350L70F, Figure 5, show that after the post-deformation annealing is observed that the morphology of the grains was not changed, but have a growing on grain size. Due the larger deformation, the recrystalization process could have occurred faster in M350L70F than M350L50F.

* Contribuição técnica ao $69^{\circ}$ Congresso Anual da ABM - Internacional e ao 14ํㅡㄹ ENEMET - Encontro Nacional de Estudantes de Engenharia Metalúrgica, de Materiais e de Minas, 21 a 25 de julho de 2014, São Paulo, SP, Brasil. 

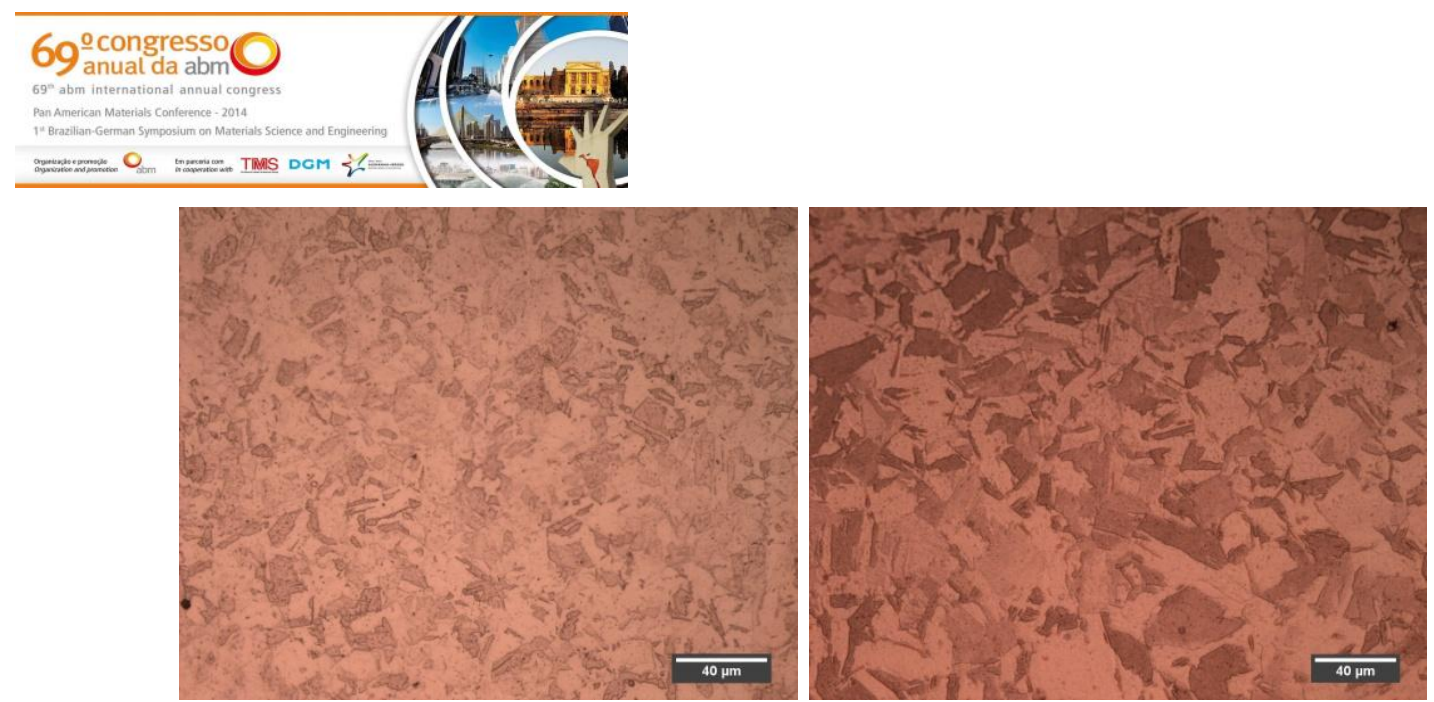

Figure 5. Optical micrographs for the M350L50F and M350L70F conditions

These conditions remain 100\% martensitic, independent of applied cold reduction. The grain growing was confirmed by a micro hardness testing were can be observed a softening of the material, the results are shown in Table 4. Carvalho [11] obtained close values to received condition.

Table 4. Micro hardness measuring of the samples

\begin{tabular}{cc}
\hline Sample & HV1 $-10 \mathrm{~s} \pm \mathrm{SD}$ \\
\hline Received & $340 \pm 8.5$ \\
\hline M350L50F & $325 \pm 6.5$ \\
\hline M350L70F & $314 \pm 8.7$
\end{tabular}

In the M350L80F condition, the microstructure showed a very small intermetallic precipitation, the electronic micrograph of this condition is shown on Figure 6.

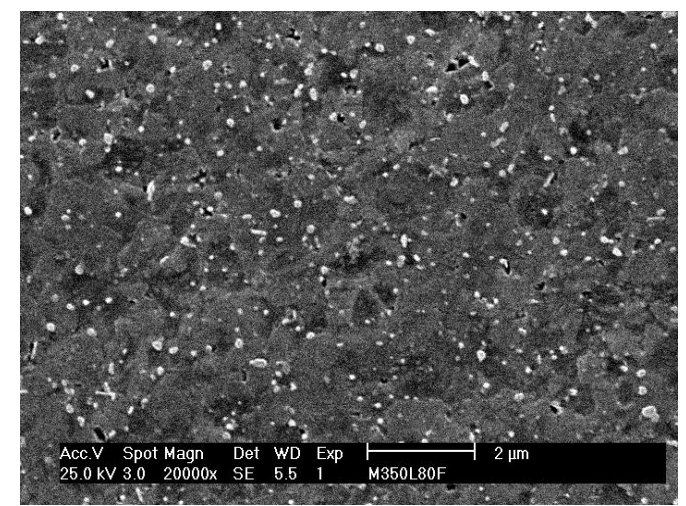

Figure 6. Electron micrograph of the M350L80F condition.

This condition achieved hardness higher than the previous conditions, 400 HV1 - 10s. Previous papers related a intermetallic precipitation on maraging steels after the post-cold rolling annealing [12] identified as Laves phase, but in a cobalt free low Ni maraging steel, according to phase diagram, get by Thermocalc software, Figure 7, is not possible the precipitation of Laves phase in Maraging 350 steel.

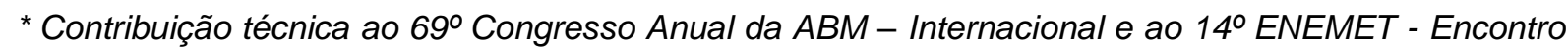
Nacional de Estudantes de Engenharia Metalúrgica, de Materiais e de Minas, 21 a 25 de julho de 2014, São Paulo, SP, Brasil. 

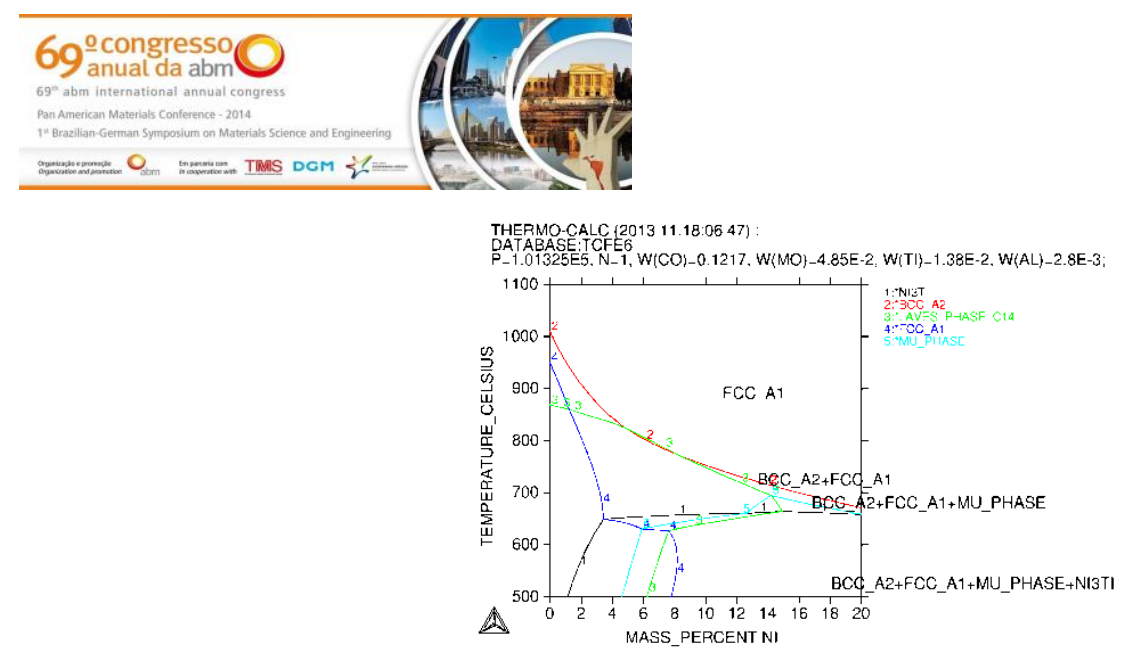

Figure 7. Phase diagram to Maraging 350 steel

Due the composition of Maraging 350 steel and the morphology of the precipitate it could be the $\mu$ phase, related $\mathrm{Ni}$ super-alloys [13] and HAZ of duplex steels welding [14]. The micrograph allows seeing a ultra-grains refinement, that could be causes by competition between the precipitation and recrystalization.

\subsection{Texture and Anisotropy Analysis}

The section of $\varphi_{2}=45^{\circ}$ of the ODFs for the annealed samples is shown in Figure 8.
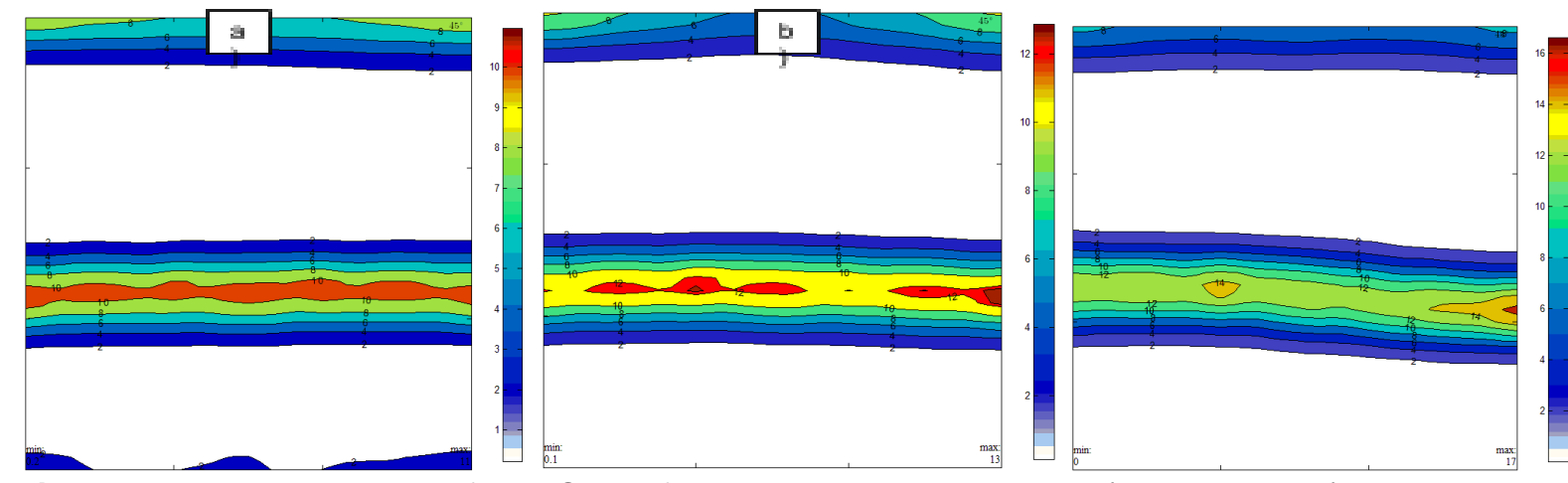

Figure 8. $\varphi_{2}=45^{\circ}$ sections of the ODFs for the annealed samples, a)M350L50F, b)M350L70F and c)M350L80F

The Figure 8 show that increasing the pre-annealing deformation there a reduction on cube on edge component and strengthen on the $\mathrm{y}$ fiber. The strength $\mathrm{y}$ fiber is good deep drawing because induces less force to draw and the slight presence of preferential directions is good to avoid the ear formation.

Analyzing the Lankford's coefficient, shown on Table 5, it was found that the planar anisotropy coefficients increase whit the deformation.

Table 5. Lankford's coefficients, planar and normal anisotropy coefficients for the specimens measured by tensile testing.

\begin{tabular}{cccccc}
\hline Sample & $\mathrm{R}_{0}$ & $\mathrm{R}_{45}$ & $\mathrm{R}_{90}$ & $\mathrm{R}_{\mathrm{m}}$ & $\Delta \mathrm{R}$ \\
\hline M350L50F & 1,03 & 1,11 & 0,98 & 1,0575 & $-0,105$ \\
\hline M350L70F & 1,12 & 1,17 & 1,2 & 1,165 & $-0,01$ \\
\hline M350L80F & 1,7 & 1,1 & 1,22 & 1,28 & 0,36 \\
\hline
\end{tabular}

* Contribuição técnica ao 69 Congresso Anual da ABM - Internacional e ao 14ํㅡㄹ ENEMET - Encontro Nacional de Estudantes de Engenharia Metalúrgica, de Materiais e de Minas, 21 a 25 de julho de 2014, São Paulo, SP, Brasil. 


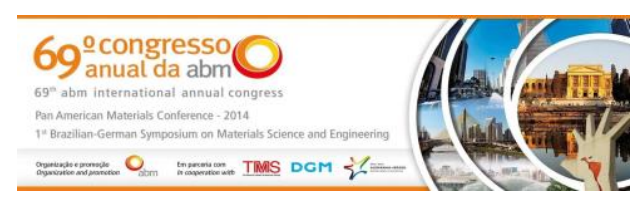

The increasing on Lankford's coefficients is unexpected since the thickness of contributes to resistance to wall thinning in deep drawing, but it could be justified due a better crystallographic texture on most cold rolled samples.

\section{CONCLUSION}

The microstructure of the maraging 350 is strongly influenced by the cold deformation before the annealing, but his hardness keeps close to initial value if there is not precipitation. The annealing texture is strongly influenced too, moving from a predominant cube on edge texture to a sharp y fiber, leading to good results in Lankford's coefficients. It was found that the cold rolling before the annealing improves the planar and normal anisotropy coefficients, but a larger deformation could lead to a intermetallic precipitation of a probable $\mu$ phase. So the best condition to make a deep drawing was found as a cold rolling to $70 \%$ in reduction of thickness followed by a annealing with a small cooling rate.

\section{Agradecimentos}

The authors thank to Brazilian Navy for providing the Maraging Steel, to CNPQ for the financial support in the beggining of this research and thanks to SENAI DR-CE/ Cento de Educação Tecnológica Afonso Figueira Rodrigues for providing the rolling of Maraging Steel.

\section{REFERÊNCIAS}

1 Magneé A, Drapier J.M., Dumont J., Coutsoradis D., Habraken L. Cobalt containg HighStrengh Steels. Bruxelles - Belgique: Centre du Informacion du Cobalt, 1974. 128p.

2 Abreu HFG. Influência da Textura Cristalográfica na Anisotropia Magnética das Ligas Fe-Mo-Ni-C. Tese de D.Sc., COPPE/UFRJ, Rio de Janeiro, RJ, Brasil, 1998.

3 Hosoya $Y$, Shima Y, Ohkita T, Nishimoto A. Texture formation and aging behavior in $18 \%$ nickel maraging steel cold rolled and austenitized by simulated continuous annealing process. Trans ISIJ 1986; 26: 798.

4 Abreu HFG,Tavares S.S.M, Silva, J.J.M., Meneses J.W.A., Bruno A.D.; The influence of an intermediate austenitization heat treatment in the texture of cold-rolled and aged 18\% Ni maraging steel. Materials Characterization, 2004; 52.

5 Freitas FNC. Adequabilidade das condições de laminação de um aço Baixo-carbono à estampagem profunda. Dissertação de M.Sc. PPGECM/CE, Fortaleza, CE, Brasil, 2003.

6 Junior EHS. Determinação do grau de conformabilidade de chapa de aço para suporte de coluna de direção e identificação de similar nacional . Dissertação, UFPR. 2002.

7 Hosford WF, Caddell RM., Metal Forming Mechanics and Metallurgical, 2ª Edição, USA, PTR Prentice Hall, 1993.

8 Farooq MA, UI H, Hashimi FH, Khan AQ. Microscopic determination of austenite in 18\% Ni Maraging Steel.

9 E8/E8M-11, Standard Test Methods for Tension Testing of Metallic Materials. American Society for Testing and Materials, Philadelphia, PA, 2009.

10 Souza Sá DHG. Caracterização metalúrgica e mecânica de ligas de ti-nb-sn para aplicação em implantes ortopédicos. São Cristóvão, SE, Brasil, 2012.

\footnotetext{
* Contribuição técnica ao $69^{\circ}$ Congresso Anual da ABM - Internacional e ao 14ํㅡㄹ ENEMET - Encontro Nacional de Estudantes de Engenharia Metalúrgica, de Materiais e de Minas, 21 a 25 de julho de 2014, São Paulo, SP, Brasil.
} 
11 Carvalho LG. Estudo dilatométrico das trasnformações de fase em aços maraging M300 e M350. Dissertação de Msc. Escola Politécnica da Universidade de São Paulo, Departamento de engenharia Metalúrgica e de materiais. 2012.

12 Mahmoudi A, Ghavidel MRZ, Nedjad HS, Heidarzadeh A, Ahmadabadi MN. Aging behavior and mechanical properties of Maraging steels in the presence of submicrocrystalline Laves phase particles. Materials Chareterization, 2011; 62.

13 Cheng KY,Jo CY, Jin T, Hu ZQ. Precipitation behavior of phase and creep rupture in single crystal superalloy CMSX-4. Journal of Alloys and Compounds, 2011; 509.

14 Guimarães RF. Efeito do teor de Molibdênio na microestrutura de juntas soldadas em ligas Fe-Cr-Mo. Tese - Universidade Federal do Ceará, Fortaleza, 2011

* Contribuição técnica ao 69 Congresso Anual da ABM - Internacional e ao 14ํㅡㄹ ENET - Encontro Nacional de Estudantes de Engenharia Metalúrgica, de Materiais e de Minas, 21 a 25 de julho de 2014, São Paulo, SP, Brasil. 